\title{
Phytotoxicity of petroleum-contaminated soil and bioremediated soil on Allophylus edulis
}

Fitotoxicidade do solo contaminado por petróleo e biorremediado em Allophylus edulis

\author{
Lucas Nogueira ${ }^{1}$, Renata Charvet Inckot ${ }^{1}$, Gedir de Oliveira Santos ${ }^{1}$,
} Luiz Antonio de Souza ${ }^{2} \&$ Cleusa Bona ${ }^{1,3}$

\begin{abstract}
This study aimed to assess the effect of petroleum-contaminated and bioremediated soils on germination, growth and anatomical structure of Allophylus edulis. We tested oil-contaminated soil, bioremediated soil and non-contaminated soil. We evaluated germination percentage, germination speed index (GSI), biomass and length of roots and shoots, total biomass, root and hypocotyl diameter, thickness of eophylls and cotyledons, leaf area, eophyll stomatal index and seedling anatomy. Germination percentage, GSI, biomass and leaf area did not differ between treatments after 30 days. Root biomass and plant height were lower in the noncontaminated treatment. Root biomass and leaf area differed between treatments after 60 days. Thickness of cotyledons was higher in bioremediated soil than in other treatments. Root and eophyll structure showed little variation in contaminated soil. We conclude that A. edulis was not affected by petroleum in contaminated and bioremediated soils and that this species has potential for phytoremediation.
\end{abstract}

Key words: hydrocarbons, seedling, germination, biomass, anatomy.

\section{Resumo}

O objetivo do trabalho foi avaliar o efeito do solo contaminado por petróleo e biorremediado na germinação, crescimento e estrutura anatômica de Allophylus edulis. Foram testados: solo contaminado por petróleo, solo biorremediado e solo não contaminado. Foram avaliados: porcentagem e índice de velocidade de germinação (GSI), biomassa e comprimento radicular e aéreo, biomassa total, diâmetro radicular e do hipocótilo, espessura dos cotilédones e eofilos, área foliar, índice estomático dos eofilos e a estrutura anatômica da plântula. A porcentagem de germinação, GSI, biomassa aérea e área foliar não diferiram entre os tratamentos após 30 dias. A biomassa radicular e o comprimento aéreo foram menores no tratamento sem contaminação. Após 60 dias, a biomassa radicular e a área foliar foram diferentes entre os tratamentos. A espessura do cotilédone, em solo biorremediado, foi maior que nos demais tratamentos. A estrutura radicular e do eofilo apresentou poucas alterações em solo contaminado. Conclui-se que $A$. edulis não foi afetada pelo solo contaminado e biorremediado, apresentando potencial para fitorremediação.

Palavras-chave: hidrocarbonetos, plântula, germinação, biomassa, anatomia.

\section{Introduction}

Petroleum and its derivatives can affect the availability of water, oxygen and nutrients in the soil (Pezeshki et al. 2000; Merkl et al. 2005; Adenipekun et al. 2008). Consequently, these substances can alter seed germination (Adam \& Duncan 2002; Ogbo 2009), growth (Adam \& Duncan 1999; Merkl et al. 2004) and plant biomass production (Malallah et al. 1996; Sharifi et al. 2007). However, in some species, germination is not affected by hydrocarbon-contaminated soils (Merkl et al. 2004; Farias et al. 2009). Petroleum contamination in the soil can even increase growth and biomass production of some plant species (Baker 1970; Merkl et al. 2004, 2005), because the stress caused by this contaminant can stimulate the synthesis of growth-regulating substances (Baker 1970). In general, the presence of hydrocarbons in the soil interferes negatively in plant development.

\footnotetext{
${ }^{1}$ Universidade Federal do Paraná, Setor de Ciências Biológicas, Depto. Botânica, Centro Politécnico, Jardim das Américas. C. P. 19031, 81531-980, Curitiba, PR, Brazil. ${ }^{2}$ Universidade Estadual de Maringá, Depto. Biologia, Av. Colombo 5790, bl. H78, 87020-900, Maringá, PR, Brazil.

${ }^{3}$ Autora para correspondência: cleusabona@ufpr.br
} 
The morpho-anatomical structure of plants can also be affected by hydrocarbons in the soil (Maranho et al. 2006; Inckot et al. 2008). Some species in petroleum-contaminated soil exhibited reduction in root-cell divisions (Achuba 2006), reduction in the meristematic region (Inckot et al. 2008), alterations in the structure of root hairs (Alkio et al. 2005), reduction in leaf area, changes in stomatal density (Adenipekun et al. 2008), and in the aspect and thickness of the epicuticular wax (Omosun et al. 2008), among other alterations.

Plant tolerance to petroleum and the ability to germinate in contaminated soil vary largely among species (Banks \& Schultz 2005; Shahriari et al. 2007), as well as within the same species (Adam \& Duncan 1999). Therefore, to identify hydrocarbon-resistant species is the first step to revegetate contaminated areas.

One way to minimize the effect of contaminants is bioremediation by microorganisms (fungi and bacteria). This technique uses live organisms to remove contaminants from the environment (Pandey et al. 2000; Collin 2001). Some studies show that germination and development of some plants are little affected in bioremediated soils (Dorn \& Salanitro 2000; Inckot et al. 2008), which facilitated vegetation restoration in those areas (Dorn \& Salanitro 2000). Nevertheless, studies on the development of species in contaminated and bioremediated soils are still rare, especially for native species. Hence, the objective of the present study was to assess the effect of petroleum-contaminated and bioremediated soils on germination, initial development and morphoanatomical structure of Allophylus edulis (A. St.-Hil., Cambess. \& A. Juss.) Radlk. (Sapindaceae).

It is believed that Allophylus edulis is a tolerant species and therefore important for restoring the vegetation of areas contaminated by petroleum. This species is present in humid and rocky soils, has good natural regeneration ability and fast growth; hence, it is recommended for the restoration of degraded ecosystems (Lorenzi 1992). With the results from the preset study it would be possible to assess whether bioremediation reduces the phytotoxic effects of contaminated soil on the germination and development of this species. Therefore, we aimed to test the following hypotheses: i) in petroleum-contaminated soils, (five years after contamination) germination, initial growth and morpho-anatomical structure of $A$. edulis are affected; ii) in bioremediated soils, germination, initial growth and morpho-anatomical structure of A. edulis are affected.

\section{Material and Methods}

Fruits of Allophylus edulis were provided by Embrapa Florestas, Colombo/PR, having been randomly collected from 12 individuals located in Colombo, state of Paraná, Brazil and then pulped under running water to obtain the seeds. The soil used for setting up the experiment was obtained in the Presidente Getúlio Vargas Refinery (REPAR/ Petrobrás), Araucária, state of Paraná, Brazil. The same area was contaminated on 16 July 2000 by four million liters of crude oil. Approximately 2.7 million liters of oil were retained by the soil, whereas c. 1.3 million liters flowed to the rivers Barigüi and Iguaçu. Two years after the accident, part of the superficial contaminant and part of the dead vegetation were mechanically removed, and most of the soil was bioremediated by heterotrophic bacteria and hydrocarbonoclastic fungi (Furtado 2002), in order to remove the contaminant that penetrated the soil.

Five years after contamination, the soil with petroleum was collected in contaminated areas that remained isolated and without intervention. The bioremediated soil was collected in areas submitted to in situ bioremediation and non-contaminated soil was also collected in the REPAR area, though in areas where the native vegetation was not reached by the petroleum. The collected soil is characterized as hydromorphic gleysol, which exhibits a gley horizon with a silty clay loam character (Carvalho et al. 2003). For each treatment, physico-chemical soil characteristics were analyzed by the Soil Sector of Universidade Federal do Paraná and Total Petroleum Hydrocarbon Content (TPH) was analyzed by LACTEC (Instituto de Tecnologia para $\mathrm{o}$ Desenvolvimento) (Tab. 1).

The soil for each treatment was sieved, homogenized and distributed in plastic trays. The trays containing contaminated soil (C), bioremediated soil (BR) and non-contaminated soil (NC) were randomly placed in a greenhouse with 20 -s nebulization every $30 \mathrm{~min}$ and average temperature $=27.5^{\circ} \mathrm{C}\left(\min .=17.5^{\circ} \mathrm{C} ; \max .=37.5^{\circ} \mathrm{C}\right)$. For each treatment, five replicates with 50 seeds each were made. We used a completely randomized design.

Germination was monitored for 30 days to determine germination percentage and germination speed index (GSI). To calculate GSI, we used the formula suggested by Maguire (1962): $\mathrm{GSI}=\mathrm{G}_{1} / \mathrm{N}_{1}+$ $\mathrm{G}_{2} / \mathrm{N}_{2}+\ldots . .+\mathrm{Gn} / \mathrm{Nn}$, where $\mathrm{G}_{1}, \mathrm{G}_{2}$ and $\mathrm{Gn}$ correspond to the number of seeds germinated in the first, second and last counts, whereas $\mathrm{N}_{1}, \mathrm{~N}_{2}$ and $\mathrm{Nn}$ correspond to the number of days after seed sowing.

For the development analysis, three plants per replicate were collected, for a total of 15 plants per 
Table 1 - Physico-chemical attributes and total petroleum hydrocarbon (TPH) in non-contaminated (NC), bioremediated (BR) and petroleum-contaminated soil (C).

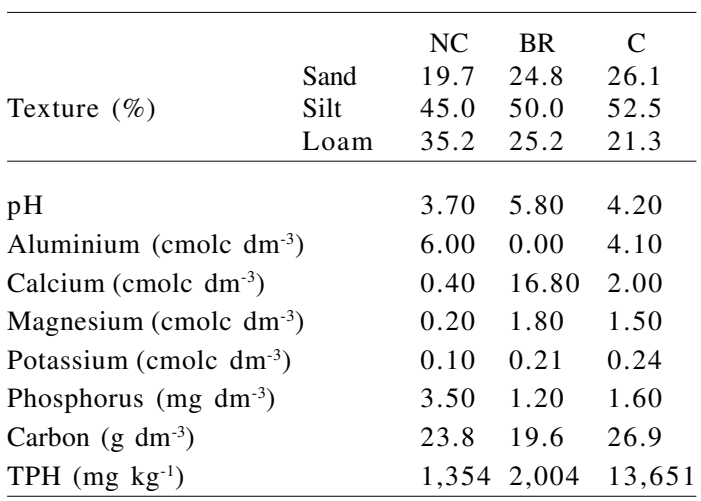

treatment. We measured length and biomass of the plant root and shoot and the eophyll area 30 and 60 days after sowing. We measured length with a millimeter ruler, whereas to determine biomass the plants were pressed, desiccated and weighed on a digital scale ( 0.1 precision). The desiccated eophylls were digitalized and their areas estimated in the program Sigma Scan Pro (Version 5.0, SPSS Inc., Chicago IL, USA).

Thirty days after sowing, we collected two seedlings per replicate, in a total of ten plants, to carry out the anatomical analysis. Lateral root samples were clarified with hypochlorite $20 \%$, stained with toluidine blue (O'Brien et al. 1964) and assembled between slide and cover slip for the observation of root hairs. Samples from the apex and from one centimeter below the apex of the main root, from the intermediate region of the hypocotyl, from the cotyledon and from the eophyll were fixed in $1 \%$ glutaraldehyde and $4 \%$ formaldehyde (McDowell \& Trump 1976). These samples were then dehydrated in alcoholic series and included in hydroxyethylmethacrylate resin, following manufacturer's instructions. Sections were performed using a rotation microtome, placed on slides stained with toluidine blue (O'Brien et al. 1964) and assembled in Permount ${ }^{\circledR}$ resin. Biochemical tests were carried out with Lugol's solution (Johansen 1940) to detect starch, ferric chloride (Johansen 1940) to detect phenolic compounds, and sudam III (Sass 1951) to detect lipids.

Microscopic analyses and photographic records were carried out with a Zeiss ${ }^{\circledR}$ optical microscope, with an attached digital camera. To measure root and hypocotyl diameter, and eophyll and cotyledon thickness one sample per seedling was collected and five cross sections were obtained. Measurements were carried out with an eyepiece grid reticle in a photonic microscope. For stomatal counting, eophyll samples were dissociated in Franklin's solution (Kraus \& Arduin 1997), stained with toluidine blue (O’Brien $e t$ al. 1964) and assembled between slide and cover slip with glycerinated gelatin (Kraus \& Arduin 1997). Stomatal counting was carried out by projecting the image of a known area $\left(1 \mathrm{~mm}^{2}\right)$, using a camera lucida attached to the microscope.

For the eophyll analysis in scanning electron microscope four seedlings per treatment were used. The samples fixed in FAA 50 were dehydrated in ethanol, subjected to the critical point with $\mathrm{CO}_{2}$ in the apparatus Bal-Tec CPD- $030^{\circledR}$, and then coated with gold in the device Balzers Union FL 9496 SCK $030^{\circledR}$. Observations were carried out in the Electron Microscopy Center of Universidade Federal do Paraná in a Jeol ${ }^{\circledR}$ scanning electron microscope (JSM-6360 LV).

Data were assessed with an analysis of variance and averages were compared with Tukey's test at 5\% significance level.

\section{Results}

Allophylus edulis germination occurred 10 days after sowing and was completed on the $19^{\text {th }}$ day. Germination percentage and GSI did not differ among treatments (Tab. 2). Thirty days after sowing, root length was longer in contaminated soil; 60 days after sowing, root length in bioremediated soil and contaminated soil did not differ from each other, and were longer than root length in non-contaminated soil (Tab. 3). Although there was a difference in length after 30 days, root diameter was similar among treatments. Root biomass, 30 days after sowing, was the same in contaminated and bioremediated soil and larger than root biomass in non-contaminated soil. After 60 days, the largest biomass was recorded for the bioremediated soil (Tab. 3).

The length of seedling shoots in bioremediated and contaminated soil was longer than in noncontaminated soil after 30 days. However, after 60 days, only the seedlings in bioremediated soil were longer. There was no statistical difference in hypocotyl diameter among treatments. Shoot biomass did not differ among treatments 30 days after sowing. However, after 60 days, shoot biomass was larger in bioremediated soil than in non-contaminated soil and similar to the biomass of plants in contaminated soil. Total biomass, 30 days after sowing, was the same among treatments and, after 60 days, it was larger in bioremediated soil, followed by contaminated soil and non-contaminated soil (Tab. 3). 
Table 2 - Germination percentage and germination speed index (GSI) of Allophylus edulis seeds subjected to treatments with non-contaminated soil (NC), bioremediated soil (BR) and petroleum-contaminated soil (C). Values represent mean \pm standard deviation; ns - not significant).

\begin{tabular}{lccr}
\hline & NC & BR & C \\
\hline Germination percentage & $58.4^{\mathrm{ns}} \pm 9.21$ & $56.8^{\mathrm{ns}} \pm 9.01$ & $54.8^{\mathrm{ns}} \pm 4.82$ \\
Germination speed index & $2.47^{\mathrm{ns}} \pm 0.43$ & $2.34^{\mathrm{ns}} \pm 0.45$ & $2.29^{\mathrm{ns}} \pm 0.20$ \\
\hline
\end{tabular}

Table 3 - Quantitative analyses of Allophylus edulis in non-contaminated soil (NC), bioremediated soil (BR) and petroleum-contaminated soil (C) 30 and 60 days after sowing. (Values represent mean \pm standard deviation. ( $n=50$ for anatomical measurements; $n=15$ for other measurements). Means followed by the same letter did not differ in Tukey's test at 5\% probability; ns - not significant).

\begin{tabular}{|c|c|c|c|c|c|c|}
\hline & \multicolumn{3}{|c|}{30 days } & \multicolumn{3}{|c|}{60 days } \\
\hline & $\mathrm{NC}$ & $\mathrm{BR}$ & $\mathrm{C}$ & $\mathrm{NC}$ & $\mathrm{BR}$ & $\mathrm{C}$ \\
\hline Root length $(\mathrm{cm})$ & $5.2^{\mathrm{b}} \pm 0.85$ & $5.5^{\mathrm{b}} \pm 0.74$ & $6.6^{\mathrm{a}} \pm 1.03$ & $5.6^{\mathrm{b}} \pm 0.25$ & $7.5^{\mathrm{a}} \pm 0.32$ & $7.3^{\mathrm{a}} \pm 0.45$ \\
\hline Root diameter $(\mu \mathrm{m})$ & $728.0^{\mathrm{ns}} \pm 101.43$ & $706.7^{\mathrm{ns}} \pm 68.16$ & $732.0^{\mathrm{ns}} \pm 115.31$ & & & \\
\hline Root biomass (mg) & $3.7^{\mathrm{b}} \pm 1.06$ & $6.2^{\mathrm{a}} \pm 1.62$ & $6.2^{\mathrm{a}} \pm 1.45$ & $10.0^{\mathrm{c}} \pm 2.37$ & $28.0^{\mathrm{a}} \pm 2.37$ & $22.5^{\mathrm{b}} \pm 3.78$ \\
\hline Shoot length $(\mathrm{cm})$ & $3.7^{\mathrm{b}} \pm 0.18$ & $4.8^{\mathrm{a}} \pm 0.38$ & $4.5^{\mathrm{a}} \pm 0.40$ & $4.5^{\mathrm{b}} \pm 0.62$ & $5.2^{\mathrm{a}} \pm 0.79$ & $5.0^{\mathrm{a} . \mathrm{b}} \pm 0.59$ \\
\hline Hypocotyl diameter $(\mu \mathrm{m})$ & $\begin{array}{l}1,236.0^{\mathrm{ns}} \\
\pm 120.47\end{array}$ & $\begin{array}{l}1,259.0^{\mathrm{ns}} \\
\pm 132.02\end{array}$ & $\begin{array}{l}1,156.0^{\mathrm{ns}} \\
\pm 104.41\end{array}$ & & & \\
\hline Shoot biomass (mg) & $26.0^{\mathrm{ns}} \pm 6.27$ & $26.5^{\mathrm{ns}} \pm 6.01$ & $25.7^{\mathrm{ns}} \pm 4.04$ & $44.1^{b} \pm 9.16$ & $60.5^{\mathrm{a}} \pm 13.19$ & $52.4^{\mathrm{a} . \mathrm{b}} \pm 10.60$ \\
\hline Total biomass (mg) & $30.0^{\mathrm{ns}} \pm 7.02$ & $32.7^{\mathrm{ns}} \pm 7.56$ & $32.0^{\mathrm{ns}} \pm 5.16$ & $54.0^{c} \pm 9.93$ & $88.5^{\mathrm{a}} \pm 17.69$ & $75.0^{\mathrm{b}} \pm 15.01$ \\
\hline Cotyledon thickness $(\mu \mathrm{m})$ & $\begin{array}{l}1,067.0^{\mathrm{b}} \\
\pm 149.68\end{array}$ & $\begin{array}{c}1,391.0^{\mathrm{a}} \\
\pm 78.62\end{array}$ & $\begin{array}{c}972.0^{\mathrm{b}} \\
\pm 138.79\end{array}$ & & & \\
\hline Stomatal index $\left(\mathrm{mm}^{2}\right)$ & $338.0^{\mathrm{ns}} \pm 34.65$ & $331.7^{\mathrm{ns}} \pm 43.07$ & $358.3^{\mathrm{ns}} \pm 64.82$ & & & \\
\hline Eophyll thickness $(\mu \mathrm{m})$ & $107.1^{\mathrm{ns}} \pm 8.15$ & $121.2^{\mathrm{ns}} \pm 23.67$ & $96.1^{\mathrm{ns}} \pm 4.35$ & & & \\
\hline Eophyll area $\left(\mathrm{cm}^{2}\right)$ & $1.2^{\mathrm{ns}} \pm 0.39$ & $1.52^{\mathrm{ns}} \pm 0.61$ & $1.54^{\mathrm{ns}} \pm 0.47$ & $1.74^{\mathrm{c}} \pm 0.51$ & $2.9^{\mathrm{a}} \pm 0.53$ & $2.0^{\mathrm{b}} \pm 0.63$ \\
\hline
\end{tabular}

Cotyledon thickness was greater in bioremediated soil than in the other treatments and did not differ between contaminated and noncontaminated soil. The stomatal index and eophyll thickness were similar among treatments. Leaf area was similar among treatments, 30 days after sowing. However, 60 days after sowing, leaf area was larger in bioremediated soil and smaller in non-contaminated soil (Tab. 3).

Roots in contaminated and bioremediated soil exhibited higher secondary branching than the roots in non-contaminated soil (Fig. 1a-c). Besides, roots in bioremediated and contaminated soil developed higher density of root hairs (Fig. 1d-f). In a longitudinal section, a similarity was observed, with little variation, as the meristematic zone of the root in contaminated and bioremediated soil was slightly smaller (Fig. 1g-i). In a cross section from the area located at one centimeter below the apex root, epidermal cells in contaminated soil were compressed and deformed (Fig. 1j-1). The endoderm stands out in all treatments due to its high phenolic content (Fig. 1m-o). The vascular cylinder of the roots in bioremediated and contaminated soil was at a slightly more advanced growth stage, at the beginning of secondary growth (Fig. 1m-o).

Alterations in the anatomical structure of the hypocotyls and cotyledon were not detected. In the eophyll, the epidermal cells of the adaxial surface exhibited similar form, epicuticular striation type and stomata in all treatments, though they were visually larger in plants in non-contaminated soil and smaller in contaminated soil compared to the treatment with bioremediated soil (Fig. 2a-c). This alteration was also visible in cross section (Fig. 2d-f). Both sides of the epidermis have cells with phenolic compounds and in the adaxial surface there was also a high incidence of mucilaginous cells, distributed in an 

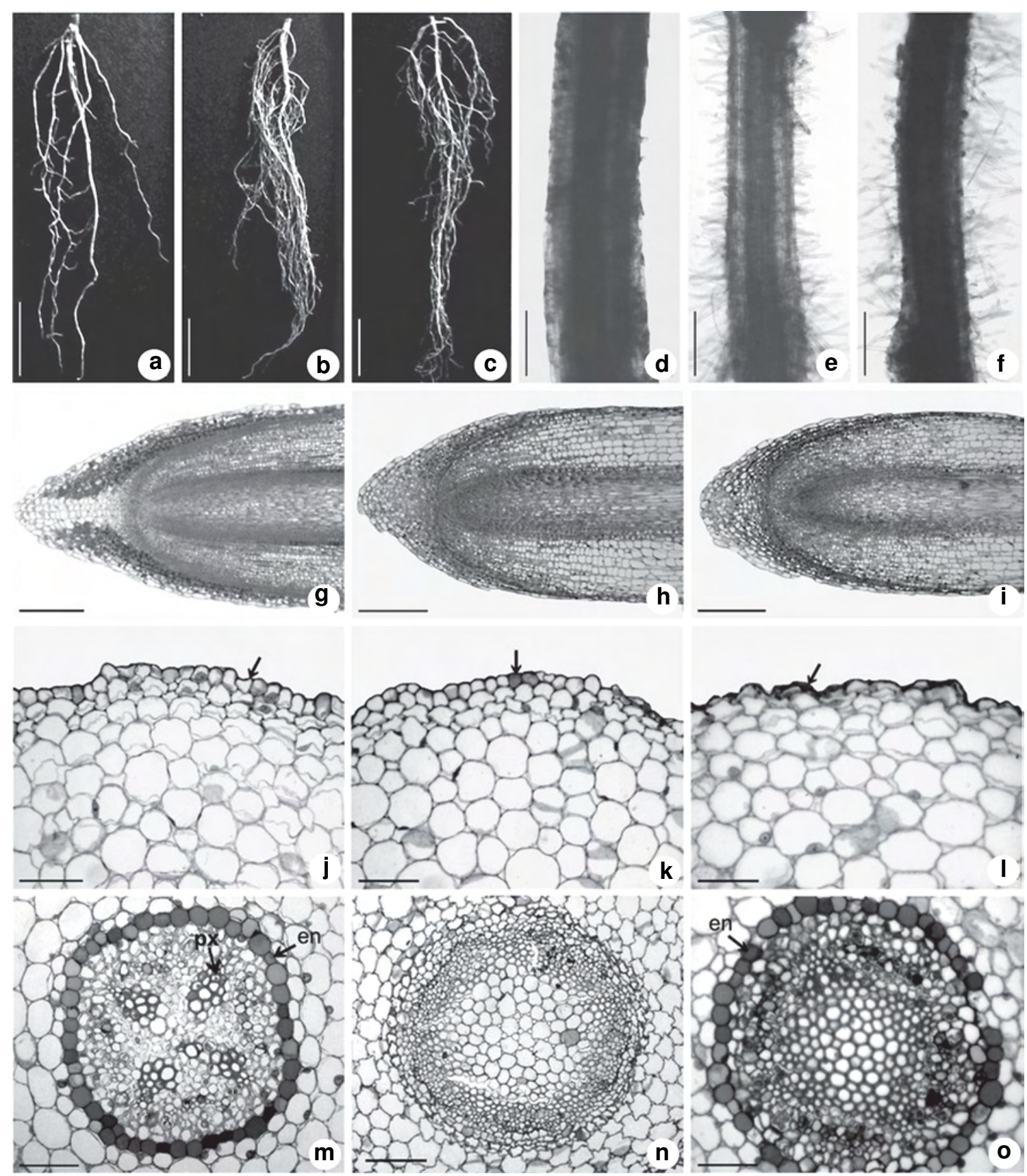

Figure 1 - Allophylus edulis root 30 days after sowing - a, d, g, j, m. non-contaminated soil; b, e, h, k, n. bioremediated soil; c, f, i, 1, o. petroleum-contaminated soil - a-c. root system; d-f. lateral root hairs; g-i. apex longitudinal section; $\mathrm{j}$-1. cortex at $1 \mathrm{~cm}$ below the apex, (arrow) epidermis; $\mathrm{m}-\mathrm{o}$. vascular cylinder at $1 \mathrm{~cm}$ below the apex, (en) endoderm; (px) protoxylem. Bar $=1 \mathrm{~cm}$ (c) $200 \mu \mathrm{m}$ (a-c); $50 \mu \mathrm{m}$ (j-o). 

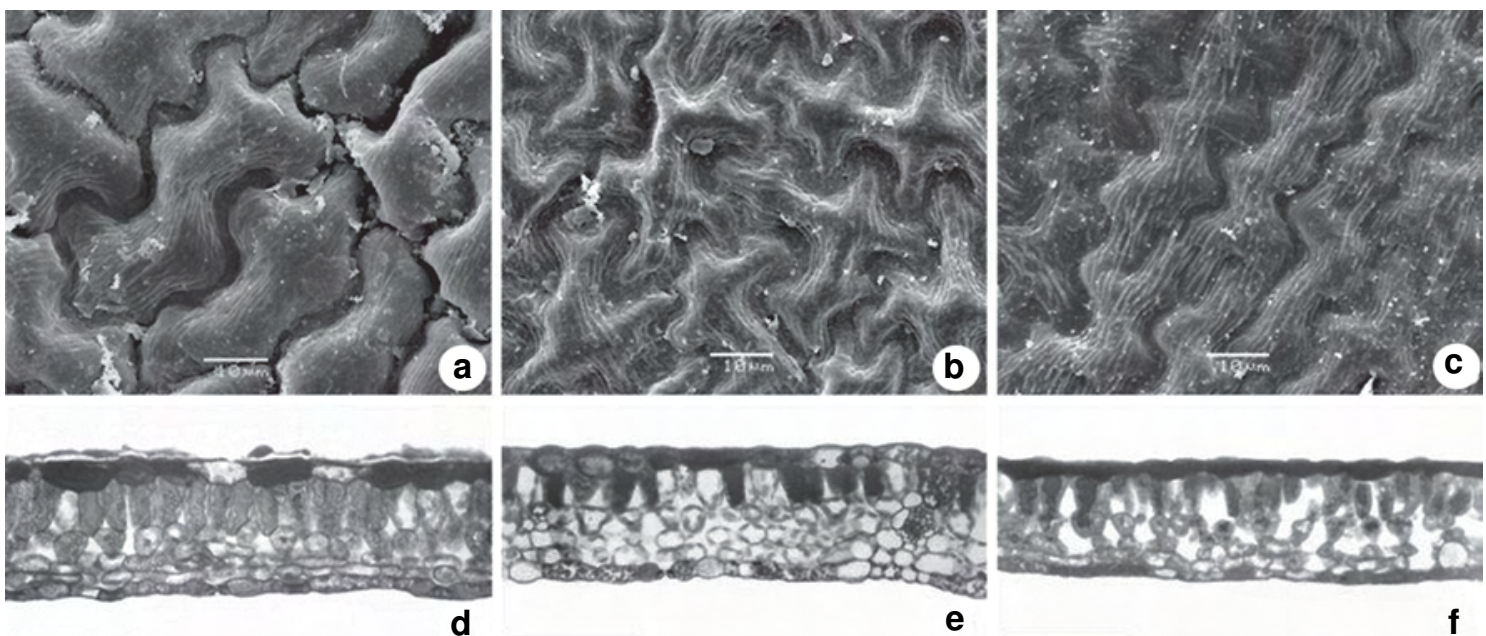

Figure 2-Allophylus edulis eophyll 30 days after sowing-a, d. non-contaminated soil; b, e. bioremediated soil; c, f. petroleumcontaminated soil - a-c. adaxial surface in scanning electron microscopy; $d-f$. cross section. $\operatorname{Bar}=100 \mu \mathrm{m}(\mathrm{d}-\mathrm{f})$.

apparently similar manner in all treatments. Mesophyll cells were also rich in phenolic compounds in all treatments, though cells were smaller and intercellular spaces were more evident in contaminated soil (Fig. 2d-f). The vascular system exhibited a similar structure in all treatments.

\section{Discussion}

The lack of interference in germination, biomass and structure of roots and shoots of Allophylus edulis shows that this species was not affected by petroleum in contaminated and bioremediated soils, and has potential for phytoremediation.

The smaller meristematic zone of the root of Allophylus edulis in contaminated and bioremediated soils did not result in lower root growth, as suggested by Inckot et al. (2008), for Mimosa pilulifera Benth., under similar conditions. In A. edulis, faster cell differentiation was observed, resulting in a shorter but not less efficient meristematic zone, since roots in contaminated and bioremediated soils were longer. These results suggest that other factors such as water and nutrient absorption are involved in root growth. Thus, it is noteworthy that A. edulis had higher development of root hairs in contaminated and bioremediated soils, which might have minimized stress caused by contamination.

It is believed that the pronounced development of lateral roots and root hairs of A. edulis in bioremediated and contaminated soils is due to the ability of this species to minimize stress caused by the low availability of water and phosphorus. This happens because the increase in root hairs maximizes absorptive surface (Esau 1977), and may also be related to the low availability of phosphorus (Ma et al. 2001). It is known that soils with hydrocarbons exhibit lower water retention (Merkl et al. 2005), and that bioremediated soils exhibit lower concentrations of nitrogen and phosphorus (Hutchinson et al. 2001), that was recorded in this experiment with A. edulis (Tab. 1).

The larger root biomass of A. edulis in contaminated and bioremediated soil is related to higher lateral root branching and to longer length, since no alteration in root thickness was recorded. It is known that oil in the soil can provide favorable conditions for root development in some species (Merkl et al. 2004, 2005). Adam \& Duncan (1999) observed that gramineous species in soil with diesel oil exhibited higher development of adventitious roots, as recorded for A.edulis. The root system of A. edulis in bioremediated soil was more similar to plants in contaminated soil than to plants in non-contaminated soil in terms of biomass, branching and elongation. This fact shows that even after bioremediation, A. edulis plants exhibited morphological alterations that characterize the reduction in water and nutrient availability in the soil. The fact that A. edulis is capable of root branching and of increasing the concentration of root hairs in contaminated and bioremediated soils might be an important survival strategy in those conditions; since a broader root system is able to obtain a greater amount of water and nutrients (Hutchinson et al. 2001). 
Cell alterations recorded in the root epidermis of A. edulis in contaminated soil were also reported for other species subjected to contamination (Omosun et al. 2008; Farias et al. 2009). These alterations are probably caused by nutrient unavailability (Gill et al. 1992) and by water stress (Omosun et al. 2008; Farias et al. 2009), caused by hydrocarbon contamination in the soil.

A. edulis did not show alterations in diameter nor in intercellular spaces in the root cortex, which indicates that there is low substrate hypoxia or that this species is unable to form aerenchyma. Aerenchyma formation can avoid not only water stress (Levitt 1980) but also anoxia (Sifton 1945) caused by hydrocarbon contamination in the soil (Baker 1970). Thereby, there are species that under the effect of contaminated soil increase intercellular spaces (Pezeshki et al. 2000) or respond to water stress by simultaneously increasing root diameter and reducing growth (Merkl et al. 2004).

For A. edulis, the conditions of the contaminated and bioremediated soils were favorable to shoot development, since in these treatments higher shoot length and biomass averages were observed, contrary to observations by other authors (Merkl et al. 2005; Omosun et al. 2008). Those results indicate that A. edulis is tolerant of the potential toxicity of the soil.

The greater cotyledon thickness of Allophylus edulis in bioremediated soil suggests that in the other treatments seedlings used nutritional reserves from the cotyledon earlier. The increase in leaf area of eophylls in contaminated and bioremediated soils, with reduction in thickness, is contrary to what was reported for most plants studied, such as Amaranthus hybridus (Omosun et al. 2008), Corchorus olitorius L. (Adenipekun et al. (2009) and Mimosa pilulifera (Inckot et al. 2008). In general, reduction in leaf area is attributed to water stress caused by the contaminant (Maranho et al. 2006; Adenipekun et al. 2008, 2009). As A. edulis exhibited an increase in leaf area of eophylls and alteration in the size of epidermic cells, it is believed that water stress was minimized by the quick response of the plant, with root branching and formation of root hairs.

Biomass of A. edulis 30 days after sowing was similar in all treatments, probably because the nutrients necessary for the onset of development came from cotyledons. Sixty days after sowing, biomass was larger in bioremediated and contaminated soils, showing once more that these soils were not phytotoxic for this species. It is believed that the growth stimulus for some species in soils with hydrocarbons can be caused by the very alterations in the soil (Merkl et al. 2004), or by the synthesis of growth-regulating substances as a response to stress (Baker 1970), followed by an increase in cell division (Bamidele \& Agbogidi 2000).

\section{Acknowledgements}

We thank Fundação Araucária for the scholarship, Petrobrás for the financial support, and the Electron Microscopy Center of Universidade Federal do Paraná.

\section{References}

Achuba, F.I. 2006. The effect of sublethal concentrations of crude oil on the growth and metabolism of Cowpea (Vigna unguiculata) seedlings. Environmental 26: 17-20.

Adam, G. \& Duncan, H. 1999. Effect of diesel fuel on growth of selected plant species. Environmental Geochemistry and Health 21: 353-357.

Adam, G. \& Duncan, H. 2002. Influence of diesel fuel on seed germination. Environmental Pollution 120: 363-370.

Adenipekun, C.O.; Oyetunji, O.J. \& Kassim, L.S. 2008. Effect of spent engine oil on the growth parameters and chlorophyll content of Corchorus olitorius Linn. Environmentalist 28: 446-450.

Adenipekun, C.O.; Oyetunji, O.J. \& Kassim, L.S. 2009. Screening of Abelmoschus esculentus L. Moench for tolerance to spent engine oil. Journal of Applied Biosciences 20:1131-1137.

Alkio, M.; Tabuchi, T.M.; Wang, X. \& Colón-Carmona, A. 2005. Stress responses to polycyclic aromatic hydrocarbons in Arabidopsis include growth inhibition and hypersensitive response-like symptoms. Journal of Experimental Botany 56: 2983-2994.

Baek, K.H.; Kim, H.S.; Oh, H.M.; Yoon, B.D.; Kim, J. \& Lee, I.S. 2004. Effects of crude oil, oil components, and bioremediation on plant growth. Journal of Environmental Science and Health, Part A 39: 2465-2472.

Baker, J.M. 1970. The effects of oils on plants. Environmental Pollution 1: 27-44.

Bamidele, J.F. \& Agbogidi, O.M. 2000. Toxic of Odidi petroleum oil and its water soluble fraction on three aquatic macrophytes. Nigerian Journal of Science and Environment 2: 113-121.

Banks, M.K. \& Schultz, K.E. 2005. Comparison of plants for germination toxicity tests in petroleumcontaminated soils. Water, Air, and Soil Pollution 167: 211-219.

Carvalho, F.J.P.C.; Castro, R.A.C.; Abdanur, A.; Krenczynki, M.C.; Teixeira, S.C.; Coneglian, D. 
2003. Relatório sobre o monitoramento do solo contaminado. Repar/SMS, Araucária. 94p.

Collin, P.H. 2001. Dictionary of Ecology and the Environment. Peter Collin Publishing, London. 560p.

Dorn, P.B. \& Salanitro, J.P. 2000. Temporal ecological assessment of oil contamined soils before and after bioremediation. Chemosphere 40: 419-426.

Esau, K. 1977. Anatomy of seed plants. 2 ed. John Willey and Sons, New York. 550p.

Farias, V.; Maranho, L.T.; Vasconcelos, E.C.; CarvalhoFilho, M.A.S.; Lacerda, L.G; Menegassi, J.A.; Pandey, A. \& Soccol, C. R. 2009. Phytodegradation potencial os Erythrina crista-galli L., Fabaceae, in petroleum-contamined soil. Applied Biochemistry and Biotechnology 157: 10-22.

Furtado, M. 2002. Petrobrás descontamina vazamento com micróbios. Revista Química e Derivados. Disponível em <http://www.quimicaederivados.com.br/revista/ qd404/ambiente1.htm>. Acesso em 06 Abr 2008.

Gill, L.S.; Nyawuame, H.G.K. \& Ehikhametalor, A.O. 1992. Effect of crude oil on the growth and anatomical features of Chromolaena odorata (L) K. e R. Newsletter 6: 1-6.

Hutchinson, S.L.; Banks, M.K. \& Schwab, A.P. 2001. Phytoremediation of aged petroleum sludge: effect of inorganic fertilizer. Journal of Environmental Quality 30: 395-403.

Inckot, R.C.; Bona, C.; Souza, L.A. de \& Santos, G.O. 2008. Anatomia das plântulas de Mimosa pilulifera (Leguminosae) crescendo em solo contaminado com petróleo e solo biorremediado. Rodriguésia 59:513-524.

Johansen, D.A. 1940. Plant microtechnique. Mc Graw Hill, New York. 523p.

Kraus, E.J. \& Arduin, M. 1997. Manual básico de métodos em morfologia vegetal. Edur, Rio de Janeiro. 198p.

Levitt, J. 1980. Responses of plants to environmental stress: water, radiation, salt and other stresses. Academic Press, New York. 297p.

Lorenzi, H. 1992. Árvores brasileiras. Plantarum, Nova Odessa. 315p.

Ma, Z.; Bielenberg, D.G.; Brown, K.M. \& Lynch, J.P. 2001. Regulation of root hair density by phosphorus availability in Arabodopsis thaliana. Plant, Cell and Environmentalist 24: 459-467.

Maguire, J.D. 1962. Speed of germination aid in selection and evaluation for seedling emergence and vigor. Crop Science 2: 176-177.

Malallah, G.; Afzal, M.; Gulshan, S.; Abraham, D.; Kurian, M. \& Dhami, M.S.I. 1996. Vicia faba as a bioindicator of oil pollution. Environmental Pollution 92: 213-217.
Maranho, L.T.; Galvão, F.; Preussler, K.H.; Muñiz, G.I.B. de \& Kuniyoshi, Y.S. 2006. Efeitos da poluição por petróleo na estrutura da folha de Podocarpus lambertii Klotzsch ex Endl., Podocarpaceae. Acta Botanica Brasilica 20: 615-624.

McDowell, E.M. \& Trump, B.F. 1976. Histologic fixatives suitable for diagnostic light and electron microscopy. Archives of Pathology and Laboratory Medicine 100: 405-414.

Merkl, N.; Schultze-Kraft, R. \& Infante, C. 2004. Phytoremediation in the tropics - the effect of crude oil on the growth of tropical plants. Bioremediation Journal 8: 177-184.

Merkl, N.; Schultze-Kraft, R. \& Infante, C. 2005. Phytoremediation in the Tropics - Influence of heavy crude oil on root morphological characteristics of graminoids. Environmental Pollution 138: 86-91.

O’Brien, T.P.; Feder, N. \& McCully, M.E. 1964. Polychromatic staining of plant cell walls by toluidine blue. Protoplasma 59: 368-373.

Ogbo, E. M. 2009. Effects of diesel fuel contamination on seed germination of four crop plants-Arachis hypogaea, Vigna unguiculata, Sorghum bicolor and Zea mays. African Journal of Biotechnology 8: 250-253.

Omosun, G.; Markson, A.A. \& Mbanasor, O. 2008. Growth and anatomy of Amaranthus hybridus as affected by diferrent crude oil concentrations. American-Eurasian Journal of Scientific Research 3: 70-74.

Pandey, A.; Soccol, C.R. \& Mitchell, D. 2000. New development in solid state fermentation: I bioprocesses and products. Process Biochemistry 35: 1153-1169.

Pezeshki, S.R.; Hester, M.W.; Lin, Q. \& Nyman, J.A. 2000. The effects of oil spill and clean-up on dominant us gulf coast marsh macrophytes: a review. Environmental Pollution 108: 129-139.

Sass, J.E. 1951. Botanical microtechnique 2ed. Iowa State College Press, Iowa. 228p.

Shahriari, M.H.; Savaghebi-Firoozabadi, G.; Azizi, M.; Kalantari, F. \& Minai-Tehrani, D. 2007. Study of growth and germination of Medicago sativa (alfalfa) in light crude oil-contaminated soil. Research Journal of Agriculture and Biological Sciences 3: 46-51.

Sharifi, M.; Sadeghi, Y. \& Akbarpour, M. 2007. Germination and growth of six plant species on contaminated soil with spent oil. International Journal of Environmental Science Technology 4: 463-470.

Sifton, H.B. 1945. Air-space tissue in plants. Botanical Review 11: 108-143. 